\title{
Identifikasi Competitive Set The Ritz-Carlton Bali
}

\author{
Ni Wayan Ayu Indah Megayanti¹, I Nyoman Sudiksa², Ida Ayu Kalpikawati ${ }^{*}$ \\ Program Studi Manajemen Divisi Kamar, Politeknik Pariwisata Bali \\ E-mail: ${ }^{1}$ ayumegayanti2@gmail.com, ${ }^{2}$ nsudiksa@gmail.com, ${ }^{3}$ idakalpika@yahoo.com \\ *Corresponding author
}

\begin{tabular}{l|l|l} 
Received: Mei, 2020 & Accepted: Mei, 2020 & Published: June, 2020
\end{tabular}

\begin{abstract}
The purpose of this study is to analyze the competitor identification by the management of The RitzCarlton Bali as well as hotels which are competitors to The Ritz-Carlton Bali. The data used in this study were secondary data and primary data obtained through data collection by observation, documentation study, and interviews to obtain information related to competitive set identification. The method used in this research is sequential mixed method design with two approaches, qualitative and quantitative approaches. The results of data analysis showed that among the 4 competitive set hotels identified by The Ritz-Carlton Bali management, only one hotel, Conrad Resort \& Spa, that has a similar corporate identity, location, size, and product type to The Ritz-Carlton Bali. Meanwhile, based on the similarity of corporate identity, location, size, product type, room rate, ADR and RevPar, the hotels which are the competitive set of The Ritz-Carlton Bali are Intercontinental Bali Resort, Conrad Bali Resort, Ayana Resort \& Spa Bali Hotel, Hilton. Bali Resort, and The Apurva Kempinski Bali.
\end{abstract}

Keywords: competitor identification; competitive Set, hospitality

\begin{abstract}
Abstrak
Tujuan dari penelitian ini adalah untuk menganalisis identifikasi pesaing yang dilakukan oleh manajemen The Ritz-Carlton Bali serta hotel-hotel yang merupakan pesaing dari The Ritz-Carlton Bali. Data yang digunakan dalam penelitian ini bersumber dari data sekunder dan data primer yang diperoleh melalui pengumpulan data dengan observasi, studi dokumentasi, dan wawancara untuk mendapatkan informasi terkait dengan identifikasi competitive set. Metode yang digunakan dalam penelitian ini adalah sequential mixed method design dengan dua pendekatan yaitu pendekatan kualitatif dan kuantitatif. Hasil analisis data menunjukkan di antara 4 hotel competitive set yang telah ditetapkan oleh manajemen The Ritz-Carlton Bali, hanya satu hotel yaitu Conrad Resort \& Spa yang memiliki identitas perusahaan, lokasi, ukuran, dan jenis produk yang serupa dengan The RitzCarlton Bali. Sementara berdasarkan pendekatan kesamaan identitas perusahaan, lokasi, ukuran, jenis produk, harga kamar, ADR dan RevPar hotel-hotel yang merupakan competitive set dari The Ritz-Carlton Bali adalah Intercontinental Bali Resort, Conrad Bali Resort, Ayana Resort \& Spa Bali Hotel, Hilton Bali Resort, dan The Apurva Kempinski Bali.
\end{abstract}

Kata kunci: identifikasi pesaing; competitive set, hospitalitas

\section{PENDAHULUAN}

The Ritz-Carlton Bali merupakan salah satu hotel yang berlokasi di area Sawangan Nusa Dua Bali. Dalam operasionalnya The Ritz-Carlton Bali menggunakan competitive set sebagai cara untuk mengetahui tingkat persaingan hotel dengan pesaing. Smith Travel 
Research (STR) dalam Zhang (2018) menyatakan bahwa "Competitive sets (comp sets) as a group of hotels by which a property can compare itself to the groups' aggregate performance." Dari pernyataan tersebut competitive set dapat diartikan sebagai sebuah kelompok yang terdiri atas beberapa hotel di mana sebuah hotel dapat membandingkan kinerjanya dengan kinerja agregat dari kelompok tersebut. Sebagai perusahaan yang berorientasi untuk meraih keuntungan, The Ritz-Carlton Bali menuntut manajemen untuk menentukan competitive set yang tepat demi memaksimalkan strategi bisnis yang akan diimplementasikan.

Manajemen The Ritz-Carlton Bali menggunakan persentase segmen pasar (market segment mix) untuk mengetahui tercapai atau tidaknya target persentase segment mix yang ditentukan. Pada Tahun 2017-2019 diketahui besaran persentase segment mix tidak sesuai dengan ketentuan yang telah ditetapkan oleh manajemen The Ritz-Carlton Bali. Salah satu segmen yang mengalami penurunan di setiap tahun adalah group. Tidak tercapainya persentase segment mix group salah satunya disebabkan relatif banyaknya tamu rombongan atau group yang melakukan pembatalan pesanan kamar di The RitzCarlton Bali. Penyebab pembatalan pesanan kamar oleh tamu rombongan dengan alasan "memilih hotel lain" menjadi alasan dengan persentase tertinggi dengan rata-rata sebesar $36,3 \%$. Berdasarkan rata-rata persentase tamu rombongan memilih hotel lain yang memilih competitive set selama Tahun 2017-2019 sangat rendah yaitu hanya mencapai $10,3 \%$ dari rata-rata persentase tamu rombongan yang memilih hotel pesaing lain sebesar $36,3 \%$. Artinya $26 \%$ pembatalan tamu rombongan untuk menginap di The Ritz-Carlton Bali selama periode 2017-2019 didominasi oleh tamu rombongan memilih hotel lain yang tidak termasuk ke dalam competitive set The Ritz-Carlton Bali. Hotel yang ditentukan sebagai competitive set oleh manajemen The Ritz-Carlton Bali adalah; Intercontinental Bali Resort, Conrad Bali Resort \& Spa, The Laguna Luxury Collection, dan The St. Regis Bali Resort. Sementara hotel-hotel yang menjadi alasan tamu rombongan untuk membatalkan pesanan kamar di The Ritz-Carlton Bali adalah; Ayana Resort \& Spa Bali Hotel, Mulia Resort, Hilton Bali Resort, dan The Apurva Kempinski Bali.

Penelitian ini berlokasi di The Ritz-Carlton Bali. Identifikasi competitive set yang dilakukan oleh manajemen The Ritz-Carlton Bali hanya berfokus pada perspektif manajerial. Terjadinya pembatalan pesanan kamar oleh tamu rombongan (group) yang didominasi oleh tamu rombongan yang memilih hotel non competitive set merupakan masalah yang terdapat di The Ritz-Carlton Bali. Berdasarkan paparan diatas, maka penelitian ini dilakukan untuk menganalisis lebih lanjut mengenai identifikasi competitive set di The Ritz-Carlton Bali.

Dalam industrial organization economics (IO), perusahaan di industri yang sama dianggap sebagai pesaing (Porter 1981; Barney 1986; Chen 1996). Menurut Basrowi (2011) pesaing merupakan perusahaan atau sekelompok orang yang mengejar pasar yang sama. Menurut Kasmir (2012) pesaing suatu perusahaan dapat dikategorikan menjadi dua yaitu pesaing yang kuat dan pesaing yang lemah. Lebih lanjut Kasmir (2012) menyatakan terdapat pula pesaing yang dekat dengan perusahaan dan memiiki produk serta layanan yang mirip atau sama dengan perusahaan tersebut. Dengan kata lain pesaing dapat didefinisikan sebagai perusahaan lain yang bergerak di industri yang sama, menawarkan produk atau jasa yang sama, dan menargetkan pasar dan pelanggan yang sama.

Porac, dkk. (1995), menyatakan competitive set merupakan kelompok pesaing yang sederhana dan cukup kecil untuk dipantau secara teratur. Smith Travel Research (STR) dalam Zhang (2018) menyatakan bahwa "Competitive sets (comp sets) as a group of hotels by which a property can compare itself to the groups' aggregate performance." Dari pernyataan tersebut competitive set dapat diartikan sebagai sebuah kelompok yang terdiri atas beberapa hotel di mana sebuah hotel dapat membandingkan kinerjanya dengan kinerja agregat dari kelompok tersebut. Competitive set dikonseptualiasikan berdasarkan 
kesamaan sumber daya, atribut perusahaan (the supply-based approach), atribut konsumen (the demand-based approach), dan tipe produk (Peteraf dan Bergen, 2003). Li dan Nettesine (2012) menyatakan bahwa menentukan competitive set di industri perhotelan dilakukan dengan mengidentifikasi properti yang memiliki Average Daily Rate (ADR) yang sama serta mempertimbangkan beberapa atribut seperti harga, lokasi, restoran, layanan kamar, fasilitas meeting, dan merek.Seperti kebanyakan industri pelayanan yang kompetitif,

ini disebabkan identifikasi pesaing berfungsi sebagai langkah pertama yang penting dalam penilaian, perumusan strategi, dan evaluasi kinerja (Kim dan Canina 2011). Identifikasi pesaing merupakan kegiatan sebuah perusahaan dalam melakukan penilaian terhadap perusahaan lain yang bergerak di industri yang sama, menawarkan produk atau jasa yang sama, dan menargetkan pasar dan pelanggan yang sama untuk mendefinisikan dan mengidentifikasi pesaing dari perusahaan tersebut (Porter, 1981; Clark dan Montgomery, 1999; Kasmir, 2006). Dalam mengidentifikasi pesaing di industri perhotelan, hotel biasanya memfokuskan upaya dengan mengidentifikasi beberapa perusahaan karena sumber daya manajerial yang terbatas dan terikat rasionalitas (Bergen dan Peteraf, 2003). Clark dan Montgomery (1999) menyatakan bahwa identifikasi pesaing adalah bidang studi yang penting karena tiga alasan. Pertama, identifikasi pesaing adalah tindakan awal yang diperlukan untuk analisis pesaing. Manajer tidak bisa, tidak boleh, dan tidak menganalisis perusahaan, tetapi hanya manajer yang mengidentifikasi sebuah perusahaan sebagai pesaing atau pesaing potensial. Kedua, identifikasi pesaing telah menjadi patokan dalam penelitian obyektif tentang penetapan struktur dan batasan pasar. Ketiga, identifikasi pesaing membentuk apa yang Porac dan Thomas (1990) anggap sebagai "cognitive ologopoly" yang dibangun oleh para manajer sebagai bagian dari model pemikiran tentang pasar di mana hotel bersaing. Identifikasi pesaing terbagi menjadi dua perspektif yaitu perspektif hotel dan perspektif tamu

Dalam mengidentifikasi pesaing, hotel menggunakan dua pendekatan yaitu pendekatan secara kualitatif (Mohammed, dkk., 2014) dan pendekatan kuantitatif (Kim dan Canina, 2011). Pendekatan kualitatif terdiri atas tiga tahapan yaitu tahap pertama berupa mendefinisikan identitas perusahaan hotel, tahap kedua melakukan observasi area pasar untuk mengetahui pesaing yang potensial, dan tahap ketiga mencocokkan dan memilih hotel pesaing dengan identitas perusahaan yang sama.

Menurut Mohammed, dkk. (2014) hotel mendefinisikan identitas perusahaannya menggunakan atribut identifikasi identitas perusahaan dan kesamaan komponen visi dan misi hotel. Atribut yang digunakan Mohammed, dkk. (2014) diadaptasi dari penelitian Balmer dan Soenen (1999) dalam mendefinisikan identitas perusahaan. Atribut tersebut adalah ACID (Actual, Communicated, Ideal, Desired Identities). ACID bertujuan untuk mengidentifikasi berbagai identitas entitas perusahaan yang mencakup identitas aktual, identitas yang dikomunikasikan, identitas ideal, dan identitas yang diinginkan (Mohammed, dkk., 2014). Kunde (dalam Nurcahyo, 2015: 80) mengemukakan pentingnya visi dan misi bagi perusahaan dalam mengelola usaha, nilai dibalik sebuah produk menjadi aspek lebih penting untuk menambah keunggulan kompetitif dalam kompetisi pasar. Menurut (Vern McGinnis dalam David, 2011:50) pernyataan misi seharusnya dapat menjelaskan perusahaan apa ini, menjelaskan apa yang dicita-citakan perusahaan, membedakan perusahaan dari yang lain, berfungsi sebagai kerangka kerja untuk mengevaluasi kegiatan saat ini, dan dinyatakan dengan jelas sehingga dapat dipahami oleh semua orang. Dengan kata lain, pernyataan misi dapat digunakan untuk mengetahui identitas perusahaan.

Dalam observasi pasar penelitian ini menggunakan atribut yang paling banyak digunakan dalam penelitian sebelumnya dalam mengidentifikasi competitive set dalam proses observasi pasar. Atribut - atribut tersebut terdiri atas lokasi, ukuran, dan jenis 
produk. Pada tahap terakhir dalam proses identifikasi pesaing, manajer hotel membuat keputusan akhir tentang siapa pesaing hotel yang harus didasarkan pada informasi yang dikumpulkan dan identitas hotel (Mohammed, dkk., 2014). Pada tahap ini manajer mengklasifikasikan hotel-hotel menjadi kelompok hotel identik. Kelompok hotel identik tersebut kemudian dievaluasi dan diidentifikasi untuk mengetahui hotel-hotel yang memiliki kecenderungan untuk menimbulkan ancaman signifikan terhadap hotel dari manajer (Mohammed, dkk., 2014).

Penelitian ini mengadopsi pendekatan kuantitatif pada penelitian Kim dan Canina (2011). Kim dan Canina (2011) menggunakan kesamaan harga kamar, Average Daily Rate (ADR), dan Revenue Per Available Room (RevPar) untuk mengidentifikasi competitive set. Kim dan Canina (2011) menyatakan bahwa selain harga, kesamaan ADR dapat digunakan untuk menentukan pesaing langsung. Integrasi kedua pendekatan ini memberikan wawasan di luar yang tersedia ketika keduanya dipertimbangkan secara terpisah (Kim dan Canina, 2011). Kim dan Canina (2011) menyatakan bahwa meskipun harga mencerminkan orientasi strategis awal properti, ADR hotel mencerminkan posisi kompetitifnya saat ini. ADR adalah indikator penilaian nilai pelanggan untuk hotel tertentu (Kim dan Canina, 2011).

Menurut penelitian sebelumnya, tamu hotel memperhatikan beberapa atribut sebagai acuan dalam memilih hotel (Zhang, 2018). Atribut-atribut yang paling sering digunakan oleh tamu dalam proses membandingkan sebuah hotel dengan hotel lainnya adalah harga, value for money, lokasi, fasilitas, ukuran, layanan, kebersihan, star rating, dan citra merk (Lien, dkk., 2015; Mohammed, dkk., 2014; Liu, dkk., 2014; Lockyer, 2005). Identifikasi competitive set melalui perspektif tamu biasanya dilakukan dengan menyebarkan survey atau kuesioner kepada tamu guna mengetahui kesamaan perspektif antara manajemen hotel dengan tamu mengenai competitive set.

Berdasarkan latar belakang yang telah diuraikan rumusan masalah yang dapat diangkat adalah:

1). Bagaimanakah identifikasi competitive set di The Ritz-Carlton Bali?

2). Hotel apakah yang merupakan competitive set dari The Ritz-Carlton Bali?

Tujuan dari penelitian ini adalah untuk mengetahui identifikasi competitive set oleh manajemen The Ritz-Carlton Bali dan untuk mengetahui hotel yang menjadi competitive set dari The Ritz-Carlton Bali.

\section{METODE PENELITIAN}

Berdasarkan kajian teori dan hasil penelitian terdahulu, dalam penelitian ini terdapat dua pendekatan yaitu pendekatan kualitatif dan pendekatan kuantitatif. Pada Gambar 1 terlihat identifikasi pesaing dilakukan dengan menggunakan dua pendekatan yaitu pendekatan kualitatif (Mohammed, dkk., 2014) dan pendekatan kuantitatif (Kim dan Canina, 2011). Hal-hal yang terkait dengan identifikasi pesaing dianalisis melalui sequential mixed method design dengan hasil akhir berupa competitive set dari The RitzCarlton Bali

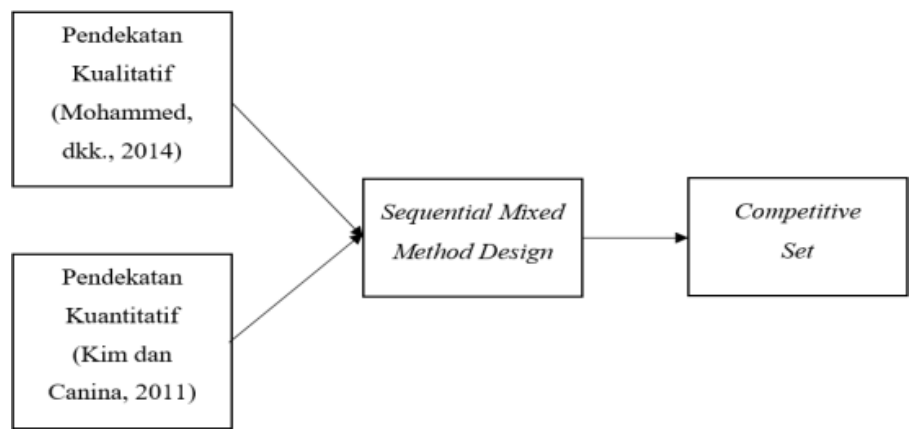




\section{Gambar 1 Kerangka Pemikiran}

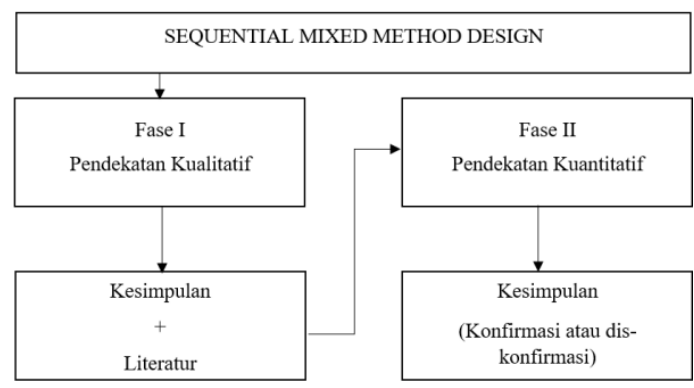

Gambar 2 Sequential Mixed Method Desgin

6 bulan selama penulis melakukan praktek kerja industri. Studi dokumentasi dilakukan untuk mempelajari dokumen laporan rekapitulasi penyebab pembatalan pesanan kamar dan laporan rapat bulanan untuk mengetahui jumlah realisasi segment mix, persentase tamu rombongan yang berpindah ke hotel lain, persentase tamu rombongan yang pindah ke hotel competitive set dan non competitive set hotel di The Ritz-Carlton Bali. Wawancara dalam penelitian ini dilakukan dengan proses wawancara terstruktur yang dilakukan langsung dengan pihak manajemen The Ritz-Carlton Bali yaitu Director of Sales and Marketing (DOSM) dari The Ritz-Carlton Bali untuk memperoleh informasi tentang penetapan competitive set dan proses identifikasi identitas perusahaan di The Ritz-Carlton Bali. Wawancara melalui telepon dilakukan untuk memperoleh pernyataan visi dan misi serta perspektif manajemen tentang identitas perusahaan dari hotel competitive set dan non competitive set.

Teknik analisis data yang digunakan penulis dalam penelitian ini adalah sequential mixed method design. Sequential mixed method design adalah teknik yang menggabungkan teknik kualitatif dan kuantitatif dalam pengumpulan dan analisis data. Dalam sequential mixed method design, satu jenis data memberikan dasar untuk pengumpulan jenis data lain yang bertujuan untuk menghubungkan data antara dua fase (Creswell, 2003).

Berdasarkan Gambar 2 terlihat bahwa sequential mixed method design terdiri atas dua fase yaitu fase pertama dan fase kedua. Pada fase pertama, dilakukan pendekatan kualitatif yang terdiri atas tiga tahap. Tahap pertama merupakan tahap mendefinisikan identitas perusahaan dari The Ritz-Carlton Bali, hotel competitive set dan non competitive set. Tahap pertama dilakukan dengan mengidentifikasi identitas perusahaan The RitzCarlstruktur ton Bali melalui wawancara dengan Director of Sales and Marketing The RitzCarlton Bali dan manajemen masing-masing hotel competitive set dan non competitive set untuk mengetahui perspektif manajerial tentang identitas perusahaan. Selanjutnya dilakukan komparasi pada pernyataan misi The Ritz-Carlton Bali, hotel competitive set, dan non competitive set, untuk mengetahui persamaan komponen pada pernyataan misi. Tahap kedua merupakan tahap observasi pasar. Pada tahap ini dilakukan pendekatan untuk melihat kedekatan lokasi, kesamaan ukuran, dan kesamaan jenis produk dari The Ritz-Carlton Bali, hotel competitive set, dan non competitive set. Tahap ketiga merupakan tahap mencocokan dan memilih hotel pesaing dengan identitas yang sama. Pada tahap ini dilakukan klasifikasi hotel menjadi kelompok yang paling identik dengan The Ritz-Carlton Bali dan membandingkan kelompok hotel tersebut untuk menentukan hotel yang paling mengancam.

Pada fase kedua, dilakukan pendekatan kuantitatif dengan membandingkan kesamaan harga kamar, ADR, dan RevPar dari The Ritz-Carlton Bali, hotel competitive set, dan hotel non competitive set. Selanjutnya, dilakukan perbandingan antara hotel 
competitive set dan hotel non competitive set yang memiliki kesamaan identitas perusahaan, lokasi, ukuran, jenis produk, harga kamar, ADR, dan RevPar dengan The RitzCarlton Bali untuk mengetahui hotel-hotel yang merupakan competitive set dari The RitzCarlton Bali

\section{HASIL DAN PEMBAHASAN}

\subsection{Deskripsi Data}

Berikut merupakan hasil penelitian dari analisis data pada fase I dan fase II sequential mixed method design.

Tabel 1 Rangkuman Persamaan The Ritz-Carlton Bali dengan Hotel Competitive Set dan Non Competitive Set

\begin{tabular}{|c|l|c|c|c|c|c|}
\hline \multirow{2}{*}{ Kategori } & \multicolumn{1}{|c|}{ Nama Hotel } & $\begin{array}{c}\text { Kesamaan } \\
\text { Identitas } \\
\text { Perusahaan }\end{array}$ & $\begin{array}{c}\text { Kedekatan } \\
\text { Lokasi }\end{array}$ & $\begin{array}{c}\text { Persamaan } \\
\text { Ukuran }\end{array}$ & $\begin{array}{c}\text { Persamaan } \\
\text { Jenis Produk }\end{array}$ & $\begin{array}{c}\text { Jumlah } \\
\text { Persamaan }\end{array}$ \\
\hline \multirow{5}{*}{ Competitive Set } & $\begin{array}{l}\text { Intercontinental Bali } \\
\text { Resort }\end{array}$ & Tidak & Tidak & Tidak & Ya & 1 \\
\cline { 2 - 7 } & $\begin{array}{l}\text { Conrad Bali Resort \& } \\
\text { Spa }\end{array}$ & Ya & Tidak & Ya & Ya & 3 \\
\cline { 2 - 7 } & $\begin{array}{l}\text { The Laguna Luxury } \\
\text { Collection }\end{array}$ & Tidak & Tidak & Ya & Ya & 2 \\
\cline { 2 - 7 } & $\begin{array}{l}\text { The St. Regis Bali } \\
\text { Resort }\end{array}$ & Tidak & Ya & Tidak & Ya & 2 \\
\hline \multirow{5}{*}{$\begin{array}{c}\text { Non } \\
\text { Competitive Set }\end{array}$} & $\begin{array}{l}\text { Ayana Resort \& Spa } \\
\text { Bali Hotel }\end{array}$ & Ya & Tidak & Ya & Ya & 3 \\
\cline { 2 - 7 } & Mulia Resort & Tidak & Ya & Tidak & Ya & 2 \\
\cline { 2 - 8 } & $\begin{array}{l}\text { The Apurva } \\
\text { Kempinski Bali }\end{array}$ & Tidak & Ya & Tidak & Ya & 2 \\
\hline
\end{tabular}

Tabel 2 Perbandingan Harga Kamar, Rata-Rata ADR, dan Rata-rata RevPar Hotel Competitive Set dan Non Competitive Set

\begin{tabular}{|c|c|c|c|c|}
\hline Kategori & Nama Hotel & $\begin{array}{c}\text { Harga } \\
\text { Kamar } \\
(\mathrm{Rp})\end{array}$ & $\begin{array}{c}\text { Rata-Rata } \\
\text { ADR } \\
\text { (Rp) }\end{array}$ & $\begin{array}{c}\text { Rata-Rata } \\
\text { RevPar } \\
\text { (Rp) }\end{array}$ \\
\hline \multirow{5}{*}{$\begin{array}{c}\text { Competitive } \\
\text { Set }\end{array}$} & $\begin{array}{l}\text { The Ritz- } \\
\text { Carlton Bali }\end{array}$ & 4.300 .000 & 4.308 .327 & 2.783 .844 \\
\hline & $\begin{array}{l}\text { Intercontinental } \\
\text { Bali Resort }\end{array}$ & 4.100 .000 & 4.141 .357 & 2.691 .882 \\
\hline & $\begin{array}{l}\text { Conrad Bali } \\
\text { Resort \& Spa }\end{array}$ & 4.250 .000 & 4.306 .357 & 2.774 .473 \\
\hline & $\begin{array}{l}\text { The Laguna } \\
\text { Luxury } \\
\text { Collection }\end{array}$ & 3.200 .000 & 3.341 .957 & 2.196 .671 \\
\hline & $\begin{array}{l}\text { The St. Regis } \\
\text { Bali Resort }\end{array}$ & 6.000 .000 & 6.471 .792 & 4.443 .481 \\
\hline \multirow{4}{*}{$\begin{array}{c}\text { Non } \\
\text { Competitive } \\
\text { Set }\end{array}$} & $\begin{array}{l}\text { Ayana Resort } \\
\text { \& Spa Bali } \\
\text { Hotel }\end{array}$ & 4.400 .000 & 4.310 .594 & 2.783 .114 \\
\hline & Mulia Resort & 3.600 .000 & 3.357 .248 & 2.347 .073 \\
\hline & $\begin{array}{l}\text { Hilton Bali } \\
\text { Resort }\end{array}$ & 4.000 .000 & 4.167 .418 & 2.778 .239 \\
\hline & $\begin{array}{l}\text { The Apurva } \\
\text { Kempinski Bali }\end{array}$ & 4.150 .000 & 4.269 .335 & 2.707 .841 \\
\hline
\end{tabular}

\subsection{Pembahasan}

Berikut ini adalah hasil dari penelitian fase I dan fase II dengan menggunakan method design:

1) Fase I sequential mixed method design

Dalam menetapkan competitive set The Ritz-Carlton Bali menggunakan atribut berupa harga, pangsa pasar, jumlah kamar, jenis produk, dan kesamaan pemilik (owner). Berdasarkan atribut yang dirujuk dalam penelitian ini (Mohammed, dkk., 
2014 dan Kim dan Canina, 2011), digunakan atribut berupa Actual, Communicated, Ideal, dan Desired Identities (ACID), pernyataan visi dan misi, lokasi, ukuran (jumlah kamar), jenis produk, harga, rata-rata ADR, dan rata-rata RevPar untuk mengidentifikasi competitive set. Berikut ini adalah tahapan dari fase I sequential mixed method design.

Berdasarkan Tabel 1 yang memuat rangkuman persamaan The Ritz-Carlton Bali dengan hotel competitive set dan non competitive set diketahui beberapa hotel yang memiliki kesamaan identitas, kedekatan lokasi, kesamaan ukuran, dan kesamaan jenis produk. Hotel-hotel tersebut adalah satu hotel yang merupakan competitive set dari The Ritz-Carlton Bali yaitu Conrad Resort \& Spa. dan dua hotel yang merupakan non competitive set dari The Ritz-Carlton Bali yaitu Ayana Resort \& Spa Bali Hotel dan Hilton Bali Resort.

2) Fase II sequential mixed method design

Tabel 2 yang memuat perbandingan harga kamar, rata-rata ADR, dan rata-rata RevPar The Ritz-Carlton Bali dengan Hotel Competitive Set dan Non Competitive Set. Pada Tabel 2 terlihat hotel competitive set dan non competitive set yang memiliki kesamaan harga kamar, rata-rata ADR dan rata-rata RevPAr dengan The Ritz-Carlton Bali. Hotel competitive set yang memiliki kesamaan harga kamar, kesamaan rata-rata ADR, dan rata-rata RevPAr dengan The Ritz-Carlton Bali adalah Intercontinental Bali Resort dan Conrad Bali Resort, sedangkan hotel non competitive set yang memiliki kesamaan rata-rata ADR dan rata-rata RevPAr dengan The Ritz-Carlton Bali adalah Ayana Resort \& Spa Bali Hotel, Hilton Bali Resort dan The Apurva Kempinski Bali. Dengan demikian hotel-hotel yang merupakan competitive set dari The Ritz-Carlton Bali adalah Intercontinental Bali Resort, Conrad Bali Resort \& Spa, Ayana Resort \& Spa Bali Hotel, Hilton Bali Resort, dan The Apurva Kempinski Bali.

\section{KESIMPULAN}

Berdasarkan hasil analisis data tentang identifikasi competitive set di The RitzCarlton Bali dapat ditarik simpulan sebagai berikut:

1) Dalam mengidentifikasi competitive set The Ritz-Carlton Bali tidak didasarkan pada kesamaan identitas perusahaan, lokasi, ukuran, dan jenis produk. Di antara 4 hotel yang ditetapkan sebagai competitive set oleh manajemen The Ritz-Carlton Bali, hanya satu hotel yaitu Conrad Resort \& Spa yang memiliki identitas perusahaan, lokasi, ukuran, dan jenis produk yang serupa dengan The Ritz-Carlton Bali.

2) Berdasarkan pendekatan kesamaan identitas perusahaan, lokasi, ukuran, jenis produk, kesamaan harga kamar, kesamaan rata-rata ADR, dan rata-rata RevPAr, maka hotelhotel yang merupakan competitive set dari The Ritz-Carlton Bali adalah Intercontinental Bali Resort, Conrad Bali Resort, Ayana Resort \& Spa Bali Hotel, Hilton Bali Resort, dan The Apurva Kempinski Bali.

Berdasarkan uraian simpulan, berikut merupakan saran yang dapat disampaikan dari hasil penelitian ini; (1) The Ritz-Carlton Bali perlu mengkaji kembali identifikasi pesaing untuk menentukan competitive set yang tepat. Pihak manajemen diharapkan dapat memahami pentingnya identifikasi pesaing karena kesalahan identifikasi pesaing dapat memengaruhi evaluasi kinerja hotel.

(2) The Ritz-Carlton Bali dapat menggunakan kesamaan identitas perusahaan, lokasi, ukuran, jenis produk, kesamaan harga kamar, kesamaan rata-rata ADR, dan rata-rata RevPAr, dalam mengidentifikasi competitive set. The Ritz-Carlton Bali juga dapat menggunakan perspektif tamu untuk membantu manajemen dalam mengidentifikasi pesaing 
Dalam hal implikasi praktis, temuan penelitian ini menunjukkan bahwa dengan menggunakan identitas perusahaan untuk mengidentifikasi pesaing, The Ritz-Carlton Bali mungkin dapat mengukur hotel yang dianggap tamu sebagai competitive set. Lebih lanjut, temuan ini juga menyiratkan bahwa dengan menggunakan identitas perusahaan untuk mengidentifikasi pesaing, hotel dapat menjadi lebih berhati-hati dalam menyampaikan sesuatu kepada publik terkait dengan dengan hotel mana mereka bersaing. Dengan kata lain, digunakannya identitas perusahaan untuk identifikasi pesaing dapat mendorong pihak Sales and Marketing Departement di dalam hotel untuk secara berkala melakukan peninjauan strategi pemasaran dan manajemen identitas untuk memastikan tidak adanya kesalahan persepsi publik terhadap identitas hotel.

Manajemen The Ritz-Carlton Bali juga dapat menambah penggunaan pendekatan kesamaan identitas perusahaan, lokasi, ukuran, jenis produk, kesamaan harga kamar, kesamaan rata-rata ADR, dan rata-rata RevPAr dalam mengidentifikasi competitive set. Diharapkan dengan digunakannya atribut sesuai dengan temuan, The Ritz-Carlton Bali dapat mengkaji kembali competitive set yang telah ditetapkan. Manajemen The Ritz-Carlton Bali juga dapat menggunakan perspektif tamu untuk mengidentifikasi competitive set, sehingga manajemen dapat mengukur kesamaan persepsi dengan tamu mengenai competitive set.

Penelitian ini dibatasi hanya pada analisis identifikasi competitive set berdasarkan perspektif dari pihak hotel yaitu The Ritz-Carlton Bali. Hal ini disebabkan data competitive set yang digunakan dalam penelitian ini merupakan competitive set yang ditetapkan oleh manajemen berdasarkan perspektif manajerial The Ritz-Carlton Bali tanpa menggunakan perspektif dari tamu. Penelitian ini dibatasi pada perspektif manajerial, terkait dengan pandemi COVID-19 yang menyebabkan penutupan penerbangan internasional serta penerbangan domestik untuk masuk ke Bali sehingga tidak dapat mengukur dari perspektif tamu terkait teknis pencarian responden. Dari perspektif akademik, mengacu pada penelitian Mohammed, dkk. (2014) dan Zhang (2018) diketahui bahwa hotel akan menentukan competitive set melalui perspektif manajerial terlebih dahulu karena manajemen hotel yang memahami tingkat persaingan. Penentuan competitive set berdasarkan perspektif tamu akan digunakan sebagai pendukung untuk mengetahui ada atau tidaknya persamaan persepsi antara hotel dengan tamu dalam mengidentifikasi pesaing.

Penelitian ini hanya berfokus pada identifikasi pesaing melalui perspektif manajerial, disarankan untuk penelitian selanjutnya agar dapat berfokus pada proses identifikasi pesaing yang melibatkan perspektif tamu. Menjadi penting bagi sebuah hotel untuk mengetahui sejauh mana persamaan perspektif antara manajemen dan tamu dalam mengidentifikasi pesaing.

\section{DAFTAR PUSTAKA}

Barney, J. B. (1986). Types of competition and the theory of strategy: Toward and Integrative Framework, Academy of Management Review, Vol 11 (4): 791-800

Balmer dan Soenen. (1999). The Acid Test of Corporate Identity Management. Journal of Marketing Management. Vol 15. No. 3, pp 69-92.

Bergen, M., dan Peteraf, M. 2(003). Competitor identification and competitor analysis :A broad-based managerial approach. Managerial and Decision Economics. Vol 23, pp 157-69.

Basrowi. (2011). Kewirausahaan untuk Perguruan Tinggi. Bogor : Ghalia Indonesia.

Chen, M.-J. (1996). Competitor analysis and interfirm rivalry: Toward a theoretical integration. Academy of Management Review. Vol 21. No. 1, pp 100-134.

Clark, B. H., dan Montgomery, D.B. (1999). "Managerial Identification of Competitors." Journal of Marketing. Vol 63. No. 3, pp 67. 
Ni Wayan Ayu Indah Megayanti, I Nyoman Sudiksa, Ida Ayu Kalpikawati

David, F. R. (2011). Strategic Management Concepts and Cases Thirteenth Edition. New Jersey: Pearson Education, Inc.

Kasmir. (2006). Kewirausahaan. Jakarta : PT. Raja Grafindo Persada

Kasmir. (2012). Kewirausahaan Cetakan ke-7. Jakarta : PT. Raja Grafindo Persada

Kim, Jin-young, and Canina Linda. (2011).“Competitive Sets for Lodging Properties.” Cornell Hospitality Quarterly. Vol 52. No. 1, pp 20-34.

Lockyer. (2005). Understanding The Dynamics of The Hotel Accommodation Purchase Decision. International Journal of Contemporary Hospitality Management.

Li, Jun, and Netessine, S. (2012). "Who Are My Competitors? - Let the Customer Decide." SSRN Electronic Journal.

Liu, J. N. K.,and Zhang, E. Y. (2014). "An Investigation of Factors Affecting Customer Selection of Online Hotel Booking Channels." International Journal of Hospitality Management. Vol 39, pp 71-83.

Lien, Che-Hui, Miin-Jye Wen, Li-Ching Huan, and Kuo-Lung Wu. (2015). "Online Hotel Booking: The Effects of Brand Image, Price, Trust and Value on Purchase Intentions." Asia Pacific Management Review 20 (4): 210-18.

Mohammed, I., Guillet, B.D. Law, R. (2014). "Competitor Set Identification in the Hotel Industry: A Case Study of a Full-Service Hotel in Hong Kong." International Journal of Hospitality Management. Vol 39. Pp 29-40.

Nurcahyo, J. R. (2015).“Keterkaitan Visi, Misi dan Values terhadap Kinerja Karyawan Perusahaan Kulit Dwi Jaya". Jurnal Khasanah Ilmu. Vol 6. No. 2, pp 78- 85.

Porter, M. E. 1981. The contributions of industrial organization to strategic management. Academy of Management Review. Vol 6. No. 4, pp 609-20.

Porac, J. F., dan Thomas, H. (1990). Taxonomic mental models in competitor definition. Academy of Management Review. Vol 15. No. 2, pp 224-240

Porac, J. F., H. Thomas, F. Wilson, dan D. Paton. (1995). Rivalry and The Industry model of Scottish Knitwear.

Peteraf, M.A., and Bergen, M.E. (2003). "Scanning Dynamic Competitive Landscapes: A Market-Based and Resource-Based Framework." Strategic Management Journal. Vol 24. No. 10.

Zhang, L. (2018). "Competitive Set Selection Comparison in The Hotel Industry: Contrasting The Hotels' and Customers' Perspectives". A Thesis Presented to the faculty of the Graduate School of Cornell University. 